\title{
Analysis of the Financial Liberalization Degree in Vietnam Based on Mattoo Index
}

\author{
Liujie Tang* \\ Economics School \\ Yunnan University of Finance and Economics \\ Kunming, China \\ yyw1101@163.com
}

\author{
Chang Liu \\ Economics School \\ Yunnan University of Finance and Economics \\ Kunming, China \\ 2512919252@qq.com
}

\begin{abstract}
Mattoo index measures the degree of financial liberalization in a country. This paper classified laws and regulations of Vietnam in banking and insurance and used Mattoo index to analyze the degree of financial liberalization in Vietnam. It concludes Vietnam's financial liberalization degree was higher than that of Asia and the Pacific. The banking liberalization degree is higher than the average of the world, and the insurance liberalization degree is lower than the average of the world.
\end{abstract}

\section{Keywords-Mattoo index; Vietnam; financial liberalization}

\section{INTRODUCTION}

The "One Belt, One Road" initiative has strengthened the relationship between China and countries along the route and promoted the coordinated development of all countries. Vietnam is an important partner of China and one of the major participating countries in the "21st Century Maritime Silk Road". In 2016, Vietnam's GDP reached 204.6 billion US dollars, a year-on-year increase of $6.21 \%$. The total China Vietnam bilateral trade was 9.82 million US dollars, and increased by $2.5 \%$ from 2015 .

In order to promote economic growth, Vietnam has increasingly integrated itself into the global economy, joined the free trade agreements (FTAs) and bilateral agreements, gradually opened various markets, actively introduced foreign investments, diversified its financial products, and thus increased the competitiveness of the Vietnamese market. Many foreign companies have used the preferential policies of the government to continue entering the Vietnamese market, stimulating the demand for related products and services such as real estate, social security and medical care, and bringing development opportunities to the local banking industry and insurance companies. Sustained economic growth and continued foreign direct investment have brought innovation to Vietnam, which has had a positive impact on its financial markets. Many countries and regions have already regarded Vietnam as a way to gain potential growth. For example, Hong Kong FWD Group, which is operating in Macau, Thailand, Indonesia and Philippines, entered Vietnam in November 2016. South Korea's Samsung Insurance is also exploring investment opportunities. At present, more and more foreign companies have entered the financial market in Vietnam, and Vietnam's financial market still has a lot of chances. This article analyzes financial liberalization degree in Vietnam based on Mattoo index, and summarizes Vietnam's relevant laws and regulations in financial sector. It can help to know Vietnam's financial sectors well, and will help deepen the future trade and financial cooperation between China and Vietnam.

Mckinnon \&Show [1] proposed the concept of financial liberalization. Financial liberalization is also called financial deepening and is opposed to financial restraint. They believe that the financial markets of developing countries are not perfect and should increase the degree of financial liberalization. Balassa [2] demonstrated the necessity of financial liberalization in developing countries. Aaditya Mattoo [3] proposed the theory of Mattoo index to measure financial liberalization. Mattoo index, which is a specific value from zero to one, can be valued from a country's specific commitments when joining WTO. The closer to 1 means the higher of the financial liberalization degree in the country. On the contrary, the closer to 0 indicates the lower of the financial liberalization degree in the country. Mai Thu Hien et al. [4] believed that, on the one hand, high financial liberalization can promote the development of financial markets and improve resource allocation; on the other hand, it can increase the systematic risk of the accidental withdrawal of speculative capital and lead to a fragile financial system. He used Mattoo Index to measure the level of financial liberalization in deposits and loans of Vietnam's banking industry. The results showed that Vietnam's value was a medium level, relatively higher than Asia but lower than all countries.

In summary, Mai Thu Hien et al. [4] conducted a further study on Mattoo index and obtained adjusted Mattoo index in Vietnam. The index obtained was lower than that without adjusting. However, Mai Thu Hien et al. [4] did not use Mattoo Index to measure the financial liberalization of insurance in Vietnam, nor did it specifically analyze the current status quo of insurance. At present, the methods of measuring financial liberalization mainly consist of single-indicator analysis and principal component analysis of multiple indicators. However, using the Mattoo index to analyze financial liberalization is few. International studies are mostly based on Aaditya Mattoo's research. Based on existing research, this paper sorts out the latest financial policies in Vietnam, uses Mattoo Index to analyze banking and insurance liberalization degree in Vietnam.

*Corresponding author 
It can help to understand Vietnam's financial liberalization more completely.

\section{THE FINANCIAL OPENNESS OF VIETNAM}

\section{A. The Foreign Banks}

The National Bank of Vietnam is responsible for banking supervision. At present, Vietnam has 98 banks in all, 55 of which are foreign banks. The four major state-owned banks, i.e. Vietnam Industrial and Commercial Bank (VIETINBANK), Vietnam Investment and Development Bank (BIDV), Vietnam Agriculture and Rural Development Bank (AGRIBANK), Vietnam Foreign Trade Commercial Bank (VIETCOMBANK) account for about $50 \%$ credit scale of the country, while other banks are smaller.

In 2017, the return on assets (ROA) of joint venture banks, $100 \%$ foreign banks, and foreign bank branches rank the fifth, lower than finance and leasing companies, Vietnam Bank for Social Policies, People's Credit Fund and Cooperative bank. It is 0.17 percentage points higher than the whole system. However, the return on equities (ROE) ranking falls to the sixth, which is 3.07 percentage points lower than the financial system. Compared with the entire banking system, foreign banks do not show high net profitability. As of June 2017, joint venture banks, $100 \%$ foreign banks, and foreign bank branches account for $9.60 \%$ of the total credit, whose asset growth rate is 1.65 percentage points lower than credits growth rate. The foreign banks rank the third in total assets, which is behind state-owned banks and joint-stock commercial banks. Overall, the assets of foreign banks are not low, but it ranks the fourth in growth rate. On one hand, it shows that the competitiveness of foreign banks' credit service is limited. On the other hand, it also reflects that the Vietnamese restrictions on foreign banks. Among all credit methods, the finance and leasing company's service is becoming more and more popular.

TABLE I.

BANKING ASSETS AND INCOME (2017, BILLION DOLLARS)

\begin{tabular}{|l|c|c|c|c|}
\hline & $\begin{array}{c}\text { Total } \\
\text { asses }\end{array}$ & $\begin{array}{c}\text { Growth } \\
\text { rate (\%) }\end{array}$ & $\begin{array}{c}\text { Return on } \\
\text { assets (\%) }\end{array}$ & $\begin{array}{c}\text { Return on } \\
\text { equity } \\
(\%)\end{array}$ \\
\hline State-owned bank & 202.78 & 18.34 & 0.46 & 9.06 \\
\hline Vietnam Social Policy Bank & 7.79 & 10.04 & 1.41 & 7.3 \\
\hline Joint-stock commercial bank & 178.75 & 17.69 & 0.5 & 7.07 \\
\hline $\begin{array}{l}\text { Joint venture bank, 100\% } \\
\text { foreign bank, branch of } \\
\text { foreign bank }\end{array}$ & 42.34 & 15.19 & 0.74 & 4.57 \\
\hline $\begin{array}{l}\text { Finance and leasing } \\
\text { companies }\end{array}$ & 6.30 & 24.07 & 3.57 & 17.4 \\
\hline Cooperate Bank & 1.28 & 9.56 & 1.88 & 11.78 \\
\hline People's Credit Fund & 4.55 & 13.84 & 0.9 & 13.4 \\
\hline Total & 443.79 & 17.62 & 0.57 & 7.64 \\
\hline & & \multicolumn{3}{|c|}{ Source: www.sbv.gov.vnaos } \\
\hline
\end{tabular}

\section{B. The Foreign Insurance Companies}

The Ministry of Finance of Vietnam established the Insurance Authority (ISA) in 2009 as a subsidiary of the Ministry of Finance to directly supervise Vietnam's insurance. As of 2016, Vietnam had 61 insurance companies, including 17 life insurance companies, 29 non-life insurance companies, 2 reinsurance companies, 12 insurance brokerage companies, and 1 foreign insurance subsidiary (Table 2). Among the 29 non- life insurance companies, 13 companies are foreign or joint ventures, and foreign companies have a market share of $16.8 \%$. A total of 5 out of 12 insurance brokerage companies are foreign brokers. Vietnam life insurance grows rapidly at an annual growth rate of $25 \%$, while non-life insurance maintains an average annual growth rate of $19.5 \%$.

According to ISA, the total insurance revenue reached 3.8 billion U.S. dollars in 2016, accounting for $2 \%$ of Vietnam's GDP, with an increase of $22.74 \%$ over 2015 . The life insurance revenue was 2.2 billion U.S. dollars, with an increase of $30.5 \%$ over 2015. Non-life insurance was US\$1.6 billion with an increase of $12.5 \%$ reached the highest in recent 10 years. Among the top five life insurance companies, which have an $86 \%$ market share, four are foreign companies, and only one is domestic. Prudential Vietnam Group holds $29.9 \%$ market share in life insurance market, followed by Bao Viet Life with $25.7 \%$, Manulife with $12.1 \%$, AIA Vietnam with $9.2 \%$ and Dai-ichi Life with $9.1 \%$ (TABLE 2).

\section{TABLE II. MAJOR INSURANCE COMPANIES}

\begin{tabular}{|c|c|c|c|c|c|c|c|}
\hline \multicolumn{4}{|c|}{ Property Insurance Company } & \multicolumn{4}{c|}{ Life Insurance Company } \\
\hline 1 & Bao Viet & 9 & ABIC & 1 & Prudential & 9 & Hanwha Life \\
\hline 2 & PVI & 10 & AAA & 2 & VCLI & 10 & PVI Sunlife \\
\hline 3 & Bao Minh & 11 & GIC & 3 & Generali & 11 & Bao Viet Life \\
\hline 4 & PJICO & 12 & Liberty & 4 & Manulife & 12 & Cathay Life \\
\hline 5 & PTI & 13 & VNI & 5 & AIA & 13 & Vietin Aviva \\
\hline 6 & $\begin{array}{c}\text { Samsung } \\
\text { Vina }\end{array}$ & 14 & $\begin{array}{c}\text { Bao } \\
\text { Long }\end{array}$ & 6 & $\begin{array}{c}\text { Dai-ichi } \\
\text { Life }\end{array}$ & 14 & $\begin{array}{c}\text { Great Eastern } \\
\text { Life }\end{array}$ \\
\hline 7 & BIC & 15 & AIG & 7 & Fubon Life & 15 & Chubb Life \\
\hline 8 & MIC & 16 & MSIG & 8 & Prevoir & 16 & Phu Hung Life \\
\hline
\end{tabular}

\section{MATTOO INDEX ANALYSIS}

\section{A. Vietnam's Foreign Financial Laws and Regulations}

\section{1) Foreign banking laws and regulations}

The laws and regulations of Vietnam's foreign banking are mainly stipulated in the "Vietnam Credit Institutions Amendment" promulgated in 2004. It contains the types and forms of business for foreign banks in Vietnam. Vietnam also promulgated other regulations about foreign banks. Table 3 summarizes the major laws and regulations concerning Vietnam's foreign banks service.

\section{2) Foreign insurance laws and regulations}

Vietnam's laws and regulations on foreign insurance service are mainly stipulated in "Law on insurance business" (Table 4). Vietnam has unifiedly managed international cooperation in the field of insurance business, and formulated policies to develop multilateralism and diversification on the basis of respect for independence, sovereignty, equality, and mutual benefit. This will encourage foreign insurance companies and insurance brokerage companies, as well as attract foreign investors to invest in Vietnam. 
TABLE III.

FOREIGN BANKING LAWS AND REGULATIONS

\begin{tabular}{|c|c|}
\hline Law & III \\
\hline Issued date & \\
\hline \multicolumn{2}{|c|}{$\begin{array}{l}\text { Article 12-Types of credit institution:1. Credit institutions set up under the } \\
\text { Vietnamese law, including State-run credit institutions, joint-stock credit } \\
\text { institutions, joint-stock institutions, cooperative credit institutions, joint-venture } \\
\text { credit institutions and credit institutions with } 100 \% \text { foreign capital. 2.Foreign } \\
\text { credit institutions that open foreign banks' branches and their representative } \\
\text { offices in Vietnam. } \\
\text { Article } 105 \text {-Forms of operation: Joint-venture credit institutions; Credit } \\
\text { institutions with 100\% foreign capital; Foreign bank's branches in Vietnam. }\end{array}$} \\
\hline Regulation & $\begin{array}{l}\text { DECREE ON ORGANIZATION AND OPERATION OF } \\
\text { FOREIGN BANK BRANCHES, JOINT-VENTURE BANKS, } \\
\text { BANKS WITH 100\% FOREIGN CAPITAL, AND } \\
\text { REPRESENTATIVE OFFICES OF FOREIGN CREDIT } \\
\text { INSTITUTIONS IN VIETNAM }\end{array}$ \\
\hline & \\
\hline \multicolumn{2}{|c|}{$\begin{array}{l}\text { Article 2- The organization and operation of branches of foreign commercial } \\
\text { oanks, joint venture banks, } 100 \% \text { foreign commercial banks, and foreign credit } \\
\text { agencies in Vietnam shall comply with this rule and other relevant Vietnam, } \\
\text { aws, if there are provisions that differ from this treaty, this treaty shall be } \\
\text { applied. }\end{array}$} \\
\hline Regulation & \\
\hline & \\
\hline \multicolumn{2}{|c|}{$\begin{array}{l}\text { Article 4- Maximum shareholding ratio of foreign investors (including existing } \\
\text { foreign shareholders) and related parties, maximum shareholding ratio of } \\
\text { foreign investors who are not foreign credit institutions and related parties, and } \\
\text { maximum shareholding ratio of foreign credit institutions and related parties, } \\
\text { and maximum shareholdings of foreign strategic investors and related parties } \\
\text { are respectively } 30 \%, 5 \%, 10 \% \text {, and } 15 \% \text { of the capital of a Vietnamese bank } \\
(15 \% \text { in special cases can be adjusted to } 15 \%-20 \%) \text {. }\end{array}$} \\
\hline
\end{tabular}

TABLE IV.

TABLE4. FOREIGN INSURANCE LAWS AND REGULATIONS

\begin{tabular}{|c|c|}
\hline Law & LAW. ON INSURANCE BUSINESS \\
\hline $\begin{array}{c}\text { Issued } \\
\text { date }\end{array}$ & $12 / 09 / 2000$ \\
\hline $\begin{array}{l}\text { Article 105-Forms of operation: Joint-venture insurance enterprise, joint- } \\
\text { venture insurance brokerage enterprise; insurance enterprise with 100\% } \\
\text { foreign investment capital, insurance brokerage enterprise with 100\% foreign } \\
\text { investment capital. } \\
\text { Article 106-conditions foe being granted the establishment and operation } \\
\text { licenses: 1.The foreign insurance enterprises and insurance brokerage } \\
\text { enterprises are operating lawfully and in the normal financial state; } 2 . \text { The } \\
\text { foreign insurance enterprises and insurance brokerage enterprises are } \\
\text { permitted by competent bodies of foreign countries to conduct insurance } \\
\text { business or insurance brokerage activities in the domains planned to be } \\
\text { carried out in Vietnam. } \\
\text { Article 107-conditions for being granted licenses to set up representative } \\
\text { offices in Vietnam: 1.The foreign insurance enterprises and insurance } \\
\text { brokerage enterprises have operated for five years or more; 2.The foreign } \\
\text { insurance enterprises and insurance brokerage enterprises have cooperative } \\
\text { ties with Vietnamese agencies, organizations. }\end{array}$ \\
\hline
\end{tabular}

\section{B. Vietnam's Specific Commitments in Banking and Insurance}

Vietnam joined WTO on January 11, 2007 and became the 150th member of the WTO. Table 5 summarizes Vietnam's specific commitments in banking and insurance services when entering the WTO. According to WTO regulations, trade in services has four modes. Mode 1 refers to cross-border supply, for example, consumers obtain loans or purchase insurance from foreign financial institutions. Mode 2 refers to consumption abroad, for example, consumers purchase insurance while traveling abroad. Mode 3 refers to commercial presence, for example, a foreign bank establishes a branch or subsidiary in a country to provide financial services. Mode 4 refers to presence of natural persons, such as establishing an independent financial adviser or bank manager in another country.

TABLE V. SPECIFIC COMMITMENTS IN BANKING AND INSURANCE

\begin{tabular}{|c|c|}
\hline Sectors & Banking(including deposits and lending) \\
\hline \multicolumn{2}{|c|}{ Commitments } \\
\hline \multicolumn{2}{|c|}{ (1)Unbound. } \\
\hline \multicolumn{2}{|c|}{ (2) None. } \\
\hline \multicolumn{2}{|c|}{ (3) None, except: } \\
\hline \multirow{2}{*}{\multicolumn{2}{|c|}{$\begin{array}{l}\text { a. Foreign credit institutions are only permitted to establish commercial presence in } \\
\text { Viet Nam in the following forms: }\end{array}$}} \\
\hline & \\
\hline \multirow{8}{*}{\multicolumn{2}{|c|}{$\begin{array}{l}\text { With respect to foreign commercial banks: representative office, branch of foreign } \\
\text { commercial bank, commercial joint venture bank with foreign capital contribution } \\
\text { not exceeding } 50 \% \text { of chartered capital, joint venture financial leasing company, } \\
100 \% \text { foreign invested financial leasing company, join venture finance company } \\
\text { and } 100 \% \text { foreign invested finance company, and, beginning on } 1 \text { April } 2007 \text {, } \\
100 \% \text { foreign-owned banks are permitted. } \\
\text { b.Equity participation: } \\
\text { For capital contribution in the form of buying shares, the total equity held by } \\
\text { foreign institutions and individuals in each Viet Nam's joint-stock commercial bank } \\
\text { may not exceed } 30 \% \text { of the bank's chartered capital, unless otherwise provided by } \\
\text { Viet Nam's laws or authorized by a Viet Nam's competent authority. }\end{array}$}} \\
\hline & \\
\hline & \\
\hline & \\
\hline & \\
\hline & \\
\hline & \\
\hline & \\
\hline Sectors & Insurance (including life insurance and non-life insurance) \\
\hline \multicolumn{2}{|c|}{ Commitments } \\
\hline \multicolumn{2}{|c|}{ (1) None for: } \\
\hline \multicolumn{2}{|c|}{$\begin{array}{l}\text { - Insurance services provided to enterprises with foreign invested capital, foreigners } \\
\text { working in Vietnam; }\end{array}$} \\
\hline \multicolumn{2}{|c|}{ - Reinsurance services; } \\
\hline \multirow{2}{*}{\multicolumn{2}{|c|}{$\begin{array}{l}\text { - Insurance services in international transportation, including insurance of risks } \\
\text { relating to. }\end{array}$}} \\
\hline & \\
\hline \multicolumn{2}{|c|}{ - Insurance broking and reinsurance broking services; } \\
\hline \multicolumn{2}{|c|}{$\begin{array}{l}\text { - Consultancy, actuarial, risk assessment and claim settlement services. } \\
\text { (2) None. }\end{array}$} \\
\hline \multicolumn{2}{|c|}{ (3) None, except: } \\
\hline & ril $2007,100 \%$ foreign-owned banks are pe \\
\hline
\end{tabular}

beginning on 1 April $2007,100 \%$ foreign-owned banks are permitted.

\section{Mattoo Index Analysis}

Mattoo [3] analyzed the financial liberalization degree in deposits, lending, life insurance and non-life insurance of a country. Taking deposits as an example, Mattoo firstly put weights on deposits of Mode 1, Mode 2, and Mode 3 in access commitments (TABLE 6), and then figured out the deposits' value of three modes (TABLE 7), and performed a weighted sum to get the deposit's Mattoo index. The deposit's Mattoo index could analyze the financial liberalization degree in deposits. The Mattoo indices in loans, life insurance, and nonlife insurance were also available. After obtaining four Mattoo indices, the overall situation of a country's banking and insurance industry could be analyzed.

TABLE VI. WEIGHTS IN INSURANCE AND BANKING

\begin{tabular}{|c|c|c|c|}
\hline & Mode 1 & Mode 2 & Mode 3 \\
\hline \multicolumn{4}{|c|}{ Banking } \\
\hline Deposits & 0.12 & 0.03 & 0.85 \\
\hline Lending & 0.20 & 0.05 & 0.75 \\
\hline \multicolumn{4}{|c|}{ Insurance } \\
\hline Life & 0.12 & 0.03 & 0.85 \\
\hline Non-life & 0.20 & 0.05 & 0.75 \\
\hline
\end{tabular}


TABLE VII.

THE VALUe BASED ON RESTRICTIVENESS

\begin{tabular}{|l|l|l|}
\hline Value & Mode 1\&Mode 2 & \multicolumn{1}{c|}{ Mode 3 } \\
\hline 0 & Unbound & Unbound \\
\hline 0.1 & Unbound & No new entry or unbound for new entry \\
\hline 0.25 & Unbound & $\begin{array}{l}\text { discretionary licensing for new entry or } \\
\text { economic needs testing for new entry }\end{array}$ \\
\hline 0.25 & Unbound & reciprocity condition \\
\hline 0.5 & partial liberalization & exemption of certain sub-sectors \\
\hline 0.5 & partial liberalization & ceiling on foreign equity at less than 50\% \\
\hline 0.75 & partial liberalization & ceiling on foreign equity at more than 50\% \\
\hline 0.75 & partial liberalization & limitation on the legal form of entry \\
\hline 0.75 & partial liberalization & other minor limitations \\
\hline 1 & full liberalization & full liberalization \\
\hline & \multicolumn{2}{|c}{ Source: Mattoo(2000); Hien et al. (2013) } \\
\hline
\end{tabular}

Mattoo pointed out that each mode assigned "unbound" to 0 , and assigned "none" to 1 . The valuation of mode 1 and 2 is simpler. For mode 3, a complex valuation is used. First, identify the most stringent measures for market access commitments. Second, get a value according to Table 7 .

For each country $\mathrm{j}$, the liberalization index $\mathrm{Lj}$, is defined as:

$$
\boldsymbol{L}^{j}=\sum w_{i} \cdot r_{i}, \quad \mathrm{i}=1,2,3
$$

wi is the weight. ri is the value of the financial measures taken by country $\mathrm{j}$ for mode $\mathrm{i}$.

According to the list of specific commitments of Vietnam's accession to the WTO (table 5), ri can be obtained from TABLE 7. Combined with the value of wi given in TABLE 6, the Mattoo Index of Vietnam's deposits, loans, life insurance and non-life insurance are calculated as follow:

$$
\begin{aligned}
& L_{\text {Deposit }}=0.12 * 0+0.03 * 1+0.85 * 0.5=0.455 \\
& L_{\text {Loan }}=0.20 * 0+0.05 * 1+0.75 * 0.5=0.425 \\
& L_{\text {Life }} 0.12 * 0.5+0.03 * 1+0.85 * 1=0.94 \\
& L_{\text {Non-life }}=0.20 * 0.5+0.05 * 1+0.75 * 0.75=0.7125
\end{aligned}
$$

According to the Mattoo index calculated by Vietnam's banking and insurance, deposits (0.455) and loans (0.425) are below 0.5 , indicating that banking liberalization degree is not high. Vietnam currently has many restrictions on market access for banking. Life insurance (0.94) and non-life insurance (0.7125) have higher liberalization indices, and the life insurance's Mattoo index is closer to 1. Compared with banking, Vietnam's insurance is more open and more marketoriented.

Compared to the world Mattoo indices (table 8), it can be seen that the banking Mattoo index of Vietnam is higher than that of Asia and the Pacific. The insurance Mattoo index is higher than all countries' average level. In Asia and the Pacific, the financial liberalization degree of Qatar, Singapore, and Malaysia is relatively low. The liberalization index of Solomon Islands is 1 and thus makes the country to reach the highest level of financial liberalization. From a global perspective, the Mattoo indices of Asia and the Pacific and Latin America countries are lower than the average of all countries. While the Mattoo indices of Africa and Eastern Europe are higher than that of other countries.
TABLE VIII. MATTOO INDICES OF ALL COUNTRIES

\begin{tabular}{|c|c|c|c|c|}
\hline \multirow{2}{*}{ Country } & \multicolumn{2}{|c|}{ Banking } & \multicolumn{2}{c|}{ Insurance } \\
\cline { 2 - 5 } & Deposits & Lending & Life insurance & $\begin{array}{c}\text { Non-life } \\
\text { insurance }\end{array}$ \\
\hline Vietnam & 0.46 & 0.43 & 0.94 & 0.71 \\
\hline Asia \& pacific & $\mathbf{0 . 3 7}$ & $\mathbf{0 . 4 3}$ & $\mathbf{0 . 4 6}$ & $\mathbf{0 . 4 6}$ \\
\hline Qatar & 0.15 & 0.25 & 0.00 & 0.25 \\
\hline Singapore & 0.12 & 0.61 & 0.12 & 0.10 \\
\hline Malaysia & 0.12 & 0.20 & 0.09 & 0.20 \\
\hline Solomon Islands & 1.00 & 1.00 & 1.00 & 1.00 \\
\hline Africa & $\mathbf{0 . 6 5}$ & $\mathbf{0 . 5 8}$ & $\mathbf{0 . 6 0}$ & $\mathbf{0 . 5 8}$ \\
\hline Eastern Europe & $\mathbf{0 . 6 0}$ & $\mathbf{0 . 6 3}$ & $\mathbf{0 . 5 2}$ & $\mathbf{0 . 5 3}$ \\
\hline Latin America & $\mathbf{0 . 4 8}$ & $\mathbf{0 . 4 5}$ & $\mathbf{0 . 3 5}$ & $\mathbf{0 . 3 1}$ \\
\hline Developed & $\mathbf{0 . 7 9}$ & $\mathbf{0 . 7 4}$ & $\mathbf{0 . 7 1}$ & $\mathbf{0 . 6 9 7}$ \\
\hline All coutry & $\mathbf{0 . 5 4}$ & $\mathbf{0 . 5 3}$ & $\mathbf{0 . 5 0}$ & $\mathbf{0 . 4 9}$ \\
\hline & \multicolumn{3}{|c}{ Source: Mattoo(2000) } \\
\hline
\end{tabular}

\section{CONCLUSIONS}

By analyzing the specific commitments of Vietnam's banking and insurance, the Mattoo Indices of financial liberalization in Vietnam are figured out. The results show that banking liberalization degree in Vietnam is lower than insurance liberalization degree.

Since Vietnam's financial reform in 1988, the financial industry has further developed. At present, there are still many problems in the financial industry. The main problems are the unreasonable banking credit structure, the shortage of talents in insurance [5], the overall performance of the financial industry is inefficient and incomplete in law [6]. Therefore, Vietnam's future financial reform should focus on adjusting the industrial structure, insisting on the steady and moderate opening of capital [7]. It is necessary to continuously improve laws and regulations and improve the efficiency of implementation.

In recent years, China have proposed active integration of the "One Belt and One Road" strategy. In the current financial cooperation with Vietnam, the RMB and VND exchange channel has been opened It is a multi-level regional currency trading, with support of interbank market transactions, based on bank counter transactions. In the future, China can expand cooperation with Vietnam in life insurance and non-life insurance business. In terms of banking sector, more Chinese banks can strengthen cooperation with Vietnam's in crossborder financing, settlement, financial innovation and services.

\section{ACKNOWLEDGMENT}

Thanks are due to the reviewer for valuable discussion.

\section{REFERENCES}

[1] McKinnon, I. Ronald. Money and capital in economic development. Brookings Institution Press, 2010.

[2] Balassa, Bela. "Financial liberalization in developing countries." Studies in Comparative International Development 25.4 (1990): 56-70.

[3] Mattoo, Aadtya. "Financial services and the WTO: liberalisation commitments of the developing and transition economies." The World Economy 23.3 (2000): 351-386.

[4] Hien, Mai Thu, and Nguyen Thi Minh Hanh. "Enhancing Capacity of Vietnam's Financial System to Fulfil its Commitments on Financial Liberalization Under GATS." (2013) 
[5] Tang Jincheng, Chen Liyong. "Research on the development of Vietnam's insurance market." Southeast Asia Review, 2012, (10):48-54. (In Chinese)
[6] Wang Luanfeng. "Path Choice of Vietnam's Financial Reform in the Post-crisis Era." Southeast Asia Review, 2011, (04): 21-24. (In Chinese)

[7] Liu Kun. "The Enlightenment of Vietnam's Financial Crisis to China." Macroeconomic Management, 2008, (08): 72-74. (In Chinese) 